\title{
Entre Linhas Nômades
}

\author{
Maria dos Remédios de Brito
}

1-Fora: Um texto quando deixa de trabalhar com a profundidade e se relaciona com o fora não pode ser mais interpretado, mas maquinado. Trata-se de encontrar a força que por ele é atravessada, levando o escritor para linhas e movimentos que sempre passam por múltiplos lugares. Escrever é afrontar as forças que atravessam o mundo. A Filosofia poderia conectar essas forças? Ora, ela não navega por essas águas, não está habilitada a se envolver com o exterior. $\mathrm{O}$ fora é traduzido por um fundo, uma essência, uma substância, o uno, a alma, a consciência, o espírito absoluto, a verdade fundada no conceito.

2-Da Loucura: Quando a loucura não necessitar de estudo específico, ela poderá ser vista como ar, uma onda, uma nuvem, que perpassa pelo pensamento, fazendo dele uma zona que se eleva até a explosão. Pensar é atingir essa zona, essa borda do caos.

3-Sujeito como multiplicidade: $\mathrm{O}$ sujeito já encontrou sua derrocada, não é um eu, não é um centro, não é um objeto. Nietzsche foi o pensador que deu outra dignidade para a palavra: sujeito é pura multiplicidade.

4- Um grito: $\mathrm{O}$ mundo múrmura um grande deserto. 
5-O transgredir: $\mathrm{O}$ que deve ser transgredido? $\mathrm{O}$ que deve ser violado quando a ideia do sagrado e do absoluto já foi abandonada? Onde fica a ideia da profanação? O que seria uma transgressão sexual? Será que tudo que é falado e pensado sobre essa questão nunca foi feito ou sentido? A transgressão sexual parece esvaziada no campo de um mundo passageiro que perdeu toda a sacralidade. Nada pode ser transgredido! 